\title{
IMPLEMENTASI PAI NIRKEKERASAN DI SD MUHAMMADIYAH 1 SIDOARJO
}

\author{
Muhammad Misbahul Munir \\ Institut Agama Islam Negeri (IAIN) Raden Intan Lampung \\ e-mail:mmisbahulmunir5@gmail.com
}

\begin{abstract}
Violence phenomenon in the school changes fun and friendly education to be full of anger. Because of that, education has important role to form student's world view as his ideology choice in the future. Parents and teachers have role to teach violence resistance values. Then, how Islamic education teacher strategy to teach the violence resistance values? The result of this research shows that violence resistance Islamic education teach no bullying attitude or moral, emphasize love each other, and build tolerance each other. The learning strategies to do that are through including tolerance and brotherhood values in curriculum and habituation to practice learning result from the class.
\end{abstract}

Fenomena kekerasan di sekolah mengubah wajah pendidikan yang menyenangkan dan ramah menjadi wajah yang penuh amarah. Wacana pendidikan menjadi paradoksal, yang seharusnya mengajarkan gotong royong, cinta kasih dan tolong menolong berbanding terbalik dan melahirkan fenomenafenomena kekerasan. Oleh karena itu, Pendidikan berperan penting dalam membentuk pandangan dunia (world view) siswa sebagai pilihan ideologinya di kemudian hari. Adapun yang berperan sebagai aktor dalam proses penanaman nilai-nilai anti kekerasan tersebut terhadap siswa ialah guru dan orang tua. Lantas, bagaimana strategi guru Pendidikan Agama Islam (PAI) menanamkan nilai-nilai anti kekerasan tersebut, yang mana tugasnya memberitahukan pengetahuan keagamaan, dan juga melaksanakan tugas pendidikan dan pembinaan bagi peserta didik. Hasil penelitian ini menunjukkan bahwa pendidikan agama Islam (PAI) nirkekerasan mengajarkan tentang sikap atau moral anti bullying (tidak diskriminatif), menekankan sifat saling menyayangi sesama (persaudaraan), dan membangun 
sikap toleransi. Strategi pembelajarannya dilakukan melalui dokumen atau kurikulum yang di dalamnya mengusung nilainilai toleransi dan persaudaraan, pembiasaan (simulasi) yang fokus pada tingkah laku peserta didik dalam mempraktikkan hasil pembelajaran di dalam kelas. Sedangkan implikasinya adalah penanaman moral pada anak yang substansinya diutamakan pada nilai-nilai Islami dan akhlak terpuji. Implikasi lain berupa penumbuhan sikap toleransi, seperti kasih sayang (rahmah), kebijaksanaan (hikmah), kemaslahatan universal (almaslahah al-ammah), dan keadilan.

Keywords : Islamic education subject, Non-violence.

\section{Pendahuluan}

Isu radikalisme agama semakin menguat dan mengguncang kehidupan berbangsa dan bernegara. ${ }^{1}$ Sebagai penduduk negeri yang baik, tentunya sangat tidak setuju apabila agama dijadikan sasaran perpecahan yang seharusnya menjadi perekat umat untuk menciptakan keamanan dan kenyamanan dalam kehidupan berbangsa dan beragama. Ironisnya, fenomena kekerasan ternyata sangat rentan terjadi pada tingkat remaja di sekolah. Dalam laporan Mendikbud, 84\% siswa pernah mengalami kekerasan di sekolah, $45 \%$ siswa laki-laki menyebutkan guru atau petugas sekolah adalah pelaku kekerasan, 40\% siswa usia 13-15 tahun melaporkan pernah mengalami kekerasan fisik oleh teman sebaya, $75 \%$ siswa mengaku pernah melakukan kekerasan di sekolah, 22\% siswa perempuan menyebutkan petugas sekolah adalah pelaku kekerasan, 50\% anak melaporkan mengalami perundungan (bullying) di sekolah. ${ }^{2}$

\footnotetext{
${ }^{1}$ Mohammad Zulfan Tadjoeddin and United Nations Support Facility for Indonesian Recovery (UNSFIR) (Indonesia), Anatomi kekerasan sosial dalam konteks transisi: kasus Indonesia 1990-2001 (Jakarta: UNSFIR, 2002), 11.

${ }^{2}$ Paparan Menteri Pendidikan dan Kebudayaan pada tanggal 25 Januari 2016.
} 
Permasalahan ini tentunya sangat tidak wajar, apalagi ada seorang pelaku pendidikan melakukan kekerasan terhadap peserta didik. Seharusnya seorang pemangku tugas pendidikan, menjadi contoh dan teladan yang digugu serta ditiru oleh anak didiknya. Selanjutnya, kasus terbaru kekerasan yang terjadi di sekolah mengutip laporan Kompas, mahasiswa Sekolah Tinggi Ilmu Pelayaran Jakarta yang bernama Amirullah Adityas Putra (18 Tahun) tewas akibat penganiayaan yang dilakukan oleh seniornya. ${ }^{3}$ Selain itu, Penganiayaan juga terjadi pada seorang siswa Madrasah Ibtidaiyah (MI) di Sumberdadi, Kecamatan Mlati, Sleman DIY, berinisial JAT (8) harus menjalani operasi kelamin. JAT yang merupakan siswa kelas dua menjalani operasi alat kelamin setelah mengalami kekerasan yang diduga dilakukan teman sekolahnya. ${ }^{4}$

Dalam kasus yang berbeda, kekerasan yang terjadi di sekolah masih banyak terjadi, seperti: Dasrul (52), guru mata pelajaran gambar teknik SMKN 2 di Kelurahan Manuruki, Kecamatan Tamalate, Makassar, Raditya Yoga Ditama (18), siswa kelas XII SMK Muhammadiyah 1 Solo, Jawa Tengah yang menganiaya gurunya sehingga harus mendapatkan 36 Jahitan di lengan kanannya, AFP seorang pelajar SMK Yayasan Darussalam di Kecamatan Panongan, Kabupaten Tangerang nekat melakukan percobaan pembunuhan kepada dua gurunya. ${ }^{5}$

3 "Taruna STIP Tewas Di Asrama, Diduga Dianiaya Seniornya Kompas.Com," accessed January 12, 2017, https://megapolitan.kompas.com/read/2017/01/11/11200271/taruna.stip.tewas .di.asrama.diduga.dianiaya.seniornya.

4 "Dianiaya Teman, Siswa MI Di Sleman Kencing Darah Dan Nyaris Impoten | Merdeka.Com,” accessed January 12, 2017, https://www.merdeka.com/peristiwa/dianiaya-teman-siswa-mi-di-slemankencing-darah-dan-nyaris-impoten.html.

5 "Deretan Kasus Kenakalan Bocah SMK Yang Aniaya Gurunya | Merdeka.Com," accessed January 12, 2017, https://www.merdeka.com/peristiwa/deretan-kasus-kenalan-bocah-smk-yanganiaya-gurunya/kesal-diminta-sabar-siswa-smk-di-solo-menganiayaguru.html. 
Belum lagi kasus kekerasan atau kelompok minoritas oleh kelompok mayoritas dalam bentuk verbal maupun non-verbal. ${ }^{6}$

Secara garis besar, faktor penyebab tindakan agresif siswa dapat terjadi karena: ${ }^{7}$ Pertama, siswa hidup dalam lingkungan lembaga pendidikan yang menjadi habitat bagi tumbuhnya subkultur kekerasan yang kemudian diwariskan dari angkatan satu ke angkatan berikutnya. Seperti dikatakan Kevin Howells bahwa kemarahan dan perilaku agresi sering kali terjadi karena dipicu pengaruh lingkungan sosial, tempat pelaku tinggal. Seorang siswa yang pernah mengalami perlakuan semena-mena, bukan tidak mungkin akan adanya aksi balas dendam karena perlakuan buruk di masa lampau.

Kedua, berkaitan dengan personality sebagian siswa yang memiliki kecenderungan pendendam, pemarah, dan cenderung bertindak agresif. Dalam pandangan psikologi klasik, kekerasan, perilaku sadis, kejahatan termasuk tindakan membunuh teman sendiri atau yang disebut perilaku agresif manusia pada dasarnya diyakini terjadi karena insting bawaan yang telah terprogram secara filogenetik. Sigmund Frued misalnya, mengemukakan bahwa agresi manusia pada dasarnya berasal dari instinct thanatos atau keinginan untuk mati (death wish) yang dimiliki setiap manusia secara alamiah.

Ketiga, adanya kehendak untuk melakukan aksi balas dendam, terutama ketika siswa yang menjadi pelaku tindak kekerasan sebelumnya pernah menjadi korban. Di sejumlah sekolah, sudah bukan rahasia lagi bahwa mata rantai terjadinya kekerasan dan pewarisan kultur kekerasan masih sulit diputus. Kekerasan yang dibungkus dengan ritual inisiasi atau bulying

6 The Wahid Institute, Lampu Merah Kebebasan Beragama", Laporan Kebebasan Beragama Dan Toleransi Di Indonesia (Jakarta: The Wahid Institute, 2011), 1.

7 mediaindonesia com developer, "Pendidikan dan Subkultur Nirkekerasan," May 2, 2017, http://mediaindonesia.com/read/detail/102904-pendidikan-dansubkultur-nirkekerasan. 
kepada siswa baru masih kerap terjadi, baik terang-terangan maupun secara terselubung. Adanya kehendak dalam diri anak akan teralisasi tanpa ada penanggulangan dari lingkungan atau bagi guru di lingkungan sekolah. Oleh karena itu, pengawasan dan pembinaan bagi kepribadian anak terutama masalah kekerasan baik fisik ataupun psikis.

Fenomena-fenomena kekerasan di atas mengubah wajah pendidikan yang menyenangkan, ramah menjadi wajah yang penuh amarah. Inti pendidikan yang berupa kebhinekaan, menyenangkan, dan cinta kasih berubah menjadi penghakiman, penganiayaan, dan pemaksaan. ${ }^{8}$ Wacana pendidikan menjadi paradoksal, yang seharusnya mengajarkan gotong royong, cinta kasih dan tolong menolong berbanding terbalik dan melahirkan fenomena-fenomena kekerasan. Padahal pendidikan berperan penting dalam membentuk pandangan dunia (world view) dari seorang siswa yang mana akan menjadi pilihan ideologinya dikemudian hari. ${ }^{9}$

Pada konteks ini, pendidikan agama Islam mempunyai posisi dominan dalam pembentukan masyarakat, dikarenakan masyarakat Indonesia yang berasaskan pada sila pertama Pancasila "Ketuhanan yang Maha Esa". Akan tetapi, jika kenyataannya kekerasan yang terjadi justru membanjiri negeri ini, maka perlu adanya transformasi terkait konsep pendidikan yang diajarkan pada setiap jenjang sekolah, terutama pendidikan agama Islam.

Pendidikan agama Islam semestinya mampu memberikan makna terkait bagaimana seorang individu berinteraksi dengan individu lain dalam masyarakat yang madani. ${ }^{10}$ Pengabaian pada aspek praktik inilah yang menjadi kelemahan pendidikan agama

8 Zainudin, Atiqa, and Dwi Purnanto, Radikalisme Keagamaan Dan Perubahan Sosial (Surakarta: MUP, 2002), 1.

9 Syafi'i Ma'arif, Islam Dalam Bingkai KeIndonesiaan Dan Kemanusiaan (Jakarta: Mizan, 2009), 239.

${ }^{10}$ Melvin, Active Learning (Bandung: Nusamedia, 2011), 27. 
Islam dewasa ini. Berpijak pada realitas tersebut, maka pengembangan pendidikan agama Islam nirkekerasan sangat dibutuhkan dalam dunia pendidikan, khususnya pendidikan Islam. ${ }^{11}$

Selanjutnya, pendidikan agama Islam dalam melakukan pengembangan paradigma, seperti halnya mengembangkan dan memilah materi secara substansial. Pengembangan materi sejarah Islam terkait peperangan yang selama ini seakan "membolehkan" peserta didik untuk melakukan kekerasan (perang fisik). Seharusnya materi tentang sejarah peperangan dan kekerasan tidak boleh diberikan secara parsial, tendensius. Namun, harus diberikan secara utuh serta lebih banyak memunculkan nilai-nilai etika dalam peperangan tersebut. Bila etika tersebut lebih ditekankan maka nilai-nilai kemanusiaan akan nampak, terlebih lagi menvisualisasikan materi sehingga dapat diserap oleh peserta didik dengan utuh.

Lebih dari itu, nirkekerasan merupakan kombinasi antara sikap, pandangan, dan aksi yang mengajak pada penyelesaian konflik secara damai. Sehingga dalam konteks ini, sikap perlawanan dalam mengatasi ketidakadilan yang dialami oleh peserta didik cenderung dilakukan secara masif, kreatif, cerdas, serta menghindarkan dari kemarahan dan kerusakan secara holistik. $^{12}$ Penanganan tindakan kekerasan dengan sebaik mungkin guna memberikan pelajaran kepada anak tanpa cara kekerasan.

Penanaman konsep ideologi yang tepat dan utuh serta mengarah pada tindakan nirkekerasan yang aplikatif tentu akan memberikan perubahan nyata bagi peserta didik pada pola pergaulannya di lingkungan sekolah. Pendidikan agama nirkekerasan inilah yang diharapkan mampu menurunkan

${ }^{11}$ Peter L. Berger, Tafsir Sosial Atas Kenyataan (Jakarta: LP3ES, 1990), 76.

12 A. Rifki Amin, Pengembangan Pendidikan Agama Islam Reinterpretasi Berbasis Interdisipliner (Yogyakarta: LKiS, 2015), 162. 
praktik-praktik kekerasan maupun aksi bullying, baik dalam bentuk verbal maupun non-verbal. ${ }^{13}$ Kondisi tersebut juga diharapkan akan berdampak positif pada kematangan psikologis peserta didik. Sehingga di kemudian hari konsep nirkekerasan menjadi paradigma baru dalam penyelesaian konflik masyarakat luas.

Dalam pengkajiannya, sebagaimana dipaparkan oleh Purnomo, pengembangan pendidikan agama Islam nirkekerasan membutuhkan perspektif sosiologi (interdisipliner) guna menjadi pisau analisis dalam menyelesaikan masalah. Bidang kajian tersebut memberikan andil besar bagi pendidikan agama Islam dalam melakukan penafsiran, pencegahan, sekaligus kuratif bagi setiap tindak kekerasan di dunia pendidikan, sehingga konsep nirkekerasan tidak hanya dihegemoni oleh suatu pemahaman teks keilmuan secara rigid oleh pelaku kekerasan. ${ }^{14}$

Dalam perspektif sosiologi, era sibernatika (cybernet) menyebabkan individu semakin potensial untuk dimanipulasi pikirannya. ${ }^{15}$ Bidang kajian tersebut menunjukkan betapa pentingnya peserta didik memperoleh kecerdasan spiritual melalui pembelajaran pendidikan agama Islam yang notebenenya merupakan ujung tombak pembelajaran moralitas dan internalisasi nilai-nilai agama bagi generasi muslim.

\section{Konsep Pendidikan Agama Islam Nirkekerasan}

Nirkekerasan merupakan dua suku kata yang berbeda nir artinya tanpa, sedangkan kekerasan (violence) gambaran atas perilaku yang disertai penggunaan kekuatan kepada orang lain,

13 Syamsul Arifin, Klaim Kemutlakan, Konflik Sosial, Dan Reorientasi Keberagaman, Dalam Agama Kekerasan: Membongkar Ekslusivisme, Ed. Armada Riyanto (Malang: Dioma, 2000), 51.

14 Agus Purnomo, Ideologi Kekerasan: Argumentasi Teologis-Sosial Radikalisme Islam (Yogyakarta: Pustaka Pelajar, 2009), 6.

15 Amin, Pengembangan Pendidikan Agama Islam Reinterpretasi Berbasis Interdisipliner, 162. 
secara terbuka (overt) maupun tertutup (covert), baik yang bersifat menyerang (offensive) maupun bertahan (devensive). ${ }^{16}$

WHO mendefinisikan kekerasan sebagai "digunakannya daya atau kekuatan fisik, baik berupa ancaman atau sebenarnya, terhadap diri sendiri atau orang lain, atau terhadap kelompok atau komunitas yang berakibat atau memiliki kemungkinan cedera, kematian, bahaya fisik, perkembangan atau kehilangan". ${ }^{17}$

Dalam pengkajiannya dari definisi di atas, nirkekrasan merupakan kombinasi antara sikap, pandangan, dan aksi yang dimaksudkan untuk mengajak orang di pihak lain secara damai supaya mengubah pendapat, pandangan, dan aksi mereka dengan capaian kedamaian pula. Oleh karena itu, dalam gerakan nirkekerasan para pelakunya tidak pernah membalas (merespon) tindakan the other dengan kekerasan. Sebaliknya, mereka meminimalkan kemarahan dan kerusakan secara holistik sambil menyampaikan pesan ketabahan yang tegas dan desakan untuk mengatasi ketidakadilan. ${ }^{18}$ Ini bukan berarti dalam sikap nirkekerasan seseorang hanya bersikap pasif tanpa perlawanan. Sebaliknya, perlawanan mereka dilakukan secara masif, kreatif, dan cerdas yang tentunya hanya berbasis (mengacu) pada prinsip nirkekerasan sehingga jauh lebih elegan.

Dengan demikian, upaya nirkekerasan melalui jalan damai saja tidak cukup, perlu cita-cita atau harapan kedamaian secara aktif untuk diraih bersama. Asumsinya, seseorang bisa melakukan aksi (cara) damai tapi di sisi lain ia bermaksud (kesengajaan) atau menimbulkan (tidak sengaja) ketimpangan. Misalnya, melakukan kebebasan eskpresi yang sebebas-

\footnotetext{
${ }^{16}$ Teori-teori kekerasan (Ghalia Indonesia, 2002), 11.

17 Helen Cowie and Dawn Jennifer, Penangannan Kekerasan Di Sekolah "Pendekatan Lingkup Sekolah Untuk Mencapai Praktik Terbaik (Jakarta: Indeks, 2009), 14.

18 Mohammed Abu-Nimer, Nirkekerasan dan Bina Damai dalam Islam: Teori dan Praktik (Pustaka Alvabet, 2010), 20.
} 
bebasnya dengan tujuan untuk memprovokasi dan menyebabkan amarah pihak lain. Atau paling tidak adanya faktor ketidaksengajaan. Yakni, meski tujuannya adalah untuk mencapai kedamaian (tanpa provokasi) tapi tidak melihat budaya sekitar yang "kaku" (anti kebebasan) sehingga menimbulkan kekerasan oleh pihak lain. ${ }^{19}$

Kata "Islam" berasal dari bahasa Arab yang memiliki beberapa makna. Pertama: Islam merupakan akar kata aslamayuslimu - islaman, yang artinya khadla'a, atau inqaada yaitu tunduk, pasrah, menyerah ketundukan, atau penyerahan diri. Hal ini berarti bahwa segala sesuatu, baik pengetahuan, sikap, perilaku maupun gaya hidup yang menunjukkan ketundukan dan kepatuhan terhadap kehendak Allah, adalah Islam. Penyerahan kepada kehendak Allah di sini bersifat mutlak, bulat, dan total dengan memenuhi segala perintah Allah dan menjauhi segala larangan-Nya. ${ }^{20}$

Pesan pendidikan yang ada pada makna pertama di atas ialah bahwa manusia diingatkan untuk selalu ingat kepada Allah SWT. Karena Dialah pencipta manusia, makhluk hidup dan alam semesta ini. Kepatuhan kepada Allah harus tercipta dari setiap pribadi manusia sebagai hamba-Nya. Karena dengan kepatuhan dan ketundukan itulah balasan-Nya sangat besar kelak di hari akhir. Kedua, kata Islam berasal dari kata salima artinya selamat. Maksudnya selamat dunia-akhirat. Dan juga Islam merupakan jalan keselamatan bagi manusia untuk meraih kebahagiaan dunia-akhirat. ${ }^{21}$

Ketiga, kata Islam berasal dari kata silmun artinya damai, yakni damai dengan Allah, damai dengan makhluk, dan damai dengan sesama. Damai dengan Allah tidak lain adalah taat

19 Amin, Pengembangan Pendidikan Agama Islam Reinterpretasi Berbasis Interdisipliner, 220-21.

20 Abd. Rahman Assegaf, Pendidikan Tanpa Kekerasan: Tipologi Kondisi, Kasus Dan Konsep (Yogyakarta: Tiara Wacana, 2004), 147.

${ }^{21}$ Assegaf, 149. 
kepada Allah dan tidak bermaksiat kepada-Nya. Taat kepada Allah berarti menjalankan segala perintah-Nya dan menjauhi segala larangan-Nya. Jika perintah Allah dilanggar dan larangan Allah dikerjakan, maka berarti telah bermaksiat kepada-Nya atau bermusuhan dengan Allah, tidak damai dengan-Nya. Damai dengan makhluk berarti memperlakukan alam semesta (flora, fauna, mineral, dan lainnya baik makhluk hidup maupun mati) sebagai sesama makhluk Allah, berinteraksi secara santun, melindungi dan melestarikan alam. Damai dengan sesama berarti hidup rukun dengan sesama manusia, tidak berbuat jahat, bahkan berbuat baik kepada sesama manusia tanpa memandang perbedaan agama, warna kulit, ras, seks, suku, bangsa, bahasa, keturunan, kekayaan, pangkat atau kedudukan, dan lain sebagainya. ${ }^{22}$

Wacana pendidikan agama Islam nirkekerasan dipahami sebagai dinamika pendidikan, sebagian orang beranggapan bahwa pendidikan keagamaan nirkekerasan mampu mengikis pandangan, sikap dan tindakan yang melibatkan kekerasan baik di sekolah maupun luar sekolah. Dalam Permenag No. 16 th. 2010 telah dijelaskan bahwa pendidikan agama memberikan pengetahuan dan membentuk sikap, kepribadian, dan keterampilan peserta didik dalam mengamalkan ajaran agamanya. $^{23}$

Menurut Ki Hajar Dewantara, pendidikan dipahami sebagai daya upaya untuk memajukan bertumbuhnya budi pekerti yang berhubungan dengan kekuatan batin dan karakter, serta pikiran, dan tubuh anak. Pola pengasuhan tanpa kekerasan memberikan proporsi yang ideal terhadap tiga dimensi kemanusiaan tersebut. Berkembang baiknya aspek kognitif, afektif dan psikomotorik anak menjadi indikator berlangsungnya proses pendidikan dan

\footnotetext{
${ }^{22}$ Assegaf, 147.

23 Peraturan Menteri Agama Republik Indonesia Nomor 16 Tahun 2010 tentang Pengelolaan Pendidikan Agama pada Sekolah.
} 
pendampingan yang berkualitas. Pendidikan yang berjalan tidak berhenti pada proses transfer of knowledge, akan tetapi hubungan di antara manusia dan "modeling"nya (transfer of attitude and values). ${ }^{24}$

Selanjutnya, menurut amanat Undang-undang Sistem Pendidikan Nasional No. 20 Tahun 2003 pada Pasal 3 dijelaskan bahwa: "Pendidikan nasional berfungsi mengembangkan kemampuan dan membentuk watak serta peradaban bangsa yang bermartabat dalam rangka mencerdaskan kehidupan bangsa, bertujuan untuk berkembangnya potensi peserta didik agar menjadi manusia yang beriman dan bertakwa kepada Tuhan Yang Maha Esa, berakhlak mulia, sehat, berilmu, cakap, kreatif, mandiri, dan menjadi warga negara yang demokratis serta bertanggung jawab". ${ }^{25}$

Pernyataan tersebut dijabarkan lagi oleh Peraturan Pemerintah No. 55 Tahun 2007 tentang Pendidikan Agama dan Pendidikan Keagamaan Pasal 2 ayat 1 yang menyatakan "pendidikan agama berfungsi membentuk manusia Indonesia yang beriman dan bertakwa kepada Tuhan Yang Maha Esa serta berakhlak mulia dan mampu menjaga kedamaian dan kerukunan hubungan inter dan antarumat beragama." Adapun dalam ayat 2 lebih dipertegas lagi bahwa "pendidikan agama bertujuan untuk berkembangnya kemampuan peserta didik dalam memahami, menghayati, dan mengamalkan nilai-nilai agama yang menyerasikan penguasaannya dalam ilmu pengetahuan, teknologi dan seni."26

Dengan demikian, dapat disimpulkan bahwa tujuan pendidikan Islam dalam konteks nirkekerasan adalah untuk

\footnotetext{
${ }^{24}$ Muhammad Andi Hakim, "Meruntuhkan Budaya Kuasa Dan Kekerasan Pada Anak: Belajar Dari Ki Hadjar Dewantara," BUANA GENDER : Jurnal Studi Gender Dan Anak 1, no. 1 (June 28, 2016): 87, https://doi.org/10.22515/bg.v1i1.64.

${ }^{25}$ Undang-undang Sistem Pendidikan Nasional No.20 Tahun 2003 Pasal 3.

${ }^{26}$ Peraturan Pemerintah No. 55 Tahun 2007 tentang Pendidikan Agama dan Pendidikan Keagamaan Pasal 2 ayat 1.
} 
membentuk manusia yang beriman dan bertakwa kepada Allah SWT secara benar yang senantiasa menggunakan pola pikir kritis, dinamis, dan kreatif tanpa kekerasan sesuai keahlian (bidang kecerdasan) masing-masing dalam berbangsa sehingga karyanya bermanfaat bagi diri sendiri dan masyarakat luas.

Pola pendidikan anti kekerasan mengupayakan kegiatan belajar mengajar menjadi sukacita, bukan semata-mata mengejar angka. Sosialisme pergaulan, kebahagiaan, ketenangan, dan rasa aman ketika siswa di sekolah. Khususnya pendidikan dasar sebagai pondasi utama. ${ }^{27}$ Sehingga dalam proses pengasuhan yang berjalan mengambil sekat sangat jauh dari kekerasan, karena pendidikan terjadi dalam suasana yang penuh cinta (unconditional love), hati yang penuh pengertian (understanding heart) serta relasi pribadi yang efektif (personal relationship) di antara pendidik maupun orang tua kepada anak. Selain itu, proses memanusiakan anak harus beriringan dengan upaya menemukan "self-hidden potential excellence" (mutiara talenta yang tersembunyi di dalam diri) setiap anak. Sehingga anak tidak berkembang dengan paksaan, melainkan dari passion dan minatnya. ${ }^{28}$

Ki Hadjar Dewantara begitu concern dalam ijtihad memerdekakan anak untuk berkembang baik dari dimensi hati, pikir dan perilakunya. Oleh karena itu, fasilitasi penting diberikan kepada anak, bukan dengan tindak kekerasan yang justru mematikan bakat dan kecenderungan setiap anak. Beragam kecerdasan yang dimiliki oleh setiap anak, antara lain kecerdasan matematis/logis, kecerdasan verbal/bahasa, kecerdasan interpersonal, kecerdasan fisik/gerak/badan, kecerdasan musikal/ritme, kecerdasan visual/ruang/spasial, dan kecerdasan intrapersonal harus difasilitasi oleh pendidik. Hal

27 Novi Poespita Candra, dkk, Sekolah Nir Kekerasan (Yogyakarta: Ifada Press, 2016), 9-10.

${ }^{28}$ Hakim, "Meruntuhkan Budaya Kuasa Dan Kekerasan Pada Anak," 87. 
tersebut merupakan salah satu bentuk keramahan simbolik terhadap anak. Bukan justru menggunakan paradigma "menjadikan" melainkan mendampingi anak untuk "menjadi". ${ }^{29}$

Melalui pola di atas, sebagaimana dipaparkan oleh Andi Hakim tidak mustahil budaya kuasa dan kekerasan pada anak akan runtuh dan terkikis habis. Pola fasilitasi lahir dari pemikiran pendidikan tentang among. Sistem among yang diajarkan Ki Hadjar Dewantara melalui pendidikan yang berjiwa kekeluargaan, kodrat alam dan kemerdekaan tersebut harus terpatri di dalam hati, nalar dan laku pendidik maupun orang tua. Kesadaran akan tanggung jawab sebagai pamomong adalah untuk mengantarkan anak menjadi manusia ideal, bukan dengan tindakan represif maupun regresif. ${ }^{30}$ Pendidikan Islam di dalamnya banyak berisikan tentang konsep pendidikan untuk kehidupan jangka panjang. Karena kehidupan yang baik tentunya berlandaskan pendidikan ataupun teori tentang bagaimana hidup yang baik dan dianjurkan dalam Islam.

Dengan dasar kekeluargaan, pendidik seharusnya mendidik dengan dasar kasih sayang kepada sesama manusia, saling menghormati dan menghargai perbedaan, tolong menolong, gotong-royong, serta menjunjung persatuan. Selanjutnya, bersendikan kodrat alam dan kemerdekaan, artinya bahwa pendidik harus memberikan kebebasan bagi peserta didik sesuai kodratnya.

Among artinya membimbing anak dengan penuh kecintaan dan mendahulukan kepentingan sang anak. Pendidik sebagai pamong tidak boleh memaksakan kehendaknya kepada peserta didik. Peserta didik diberikan kebebasan dengan batasan tanggung jawab. Melalui sistem among peserta didik dapat berkembang menurut kodratnya sebagai mahluk individu maupun mahluk sosial. Sehingga melalui beragam tahapan dan

\footnotetext{
${ }^{29}$ Hakim, 87-88.

${ }^{30}$ Hakim, 88.
} 
dinamika yang terjadi, akan melahirkan tatanan konsep yang kokoh tentang pola pengasuhan dan pendidikan nirkekerasan pada anak. ${ }^{31}$ Pengasuhan yang baik pada anak memberikan dampak yang besar untuk masa depannya. Karena, dengan pengasuhan yang baik anak akan menjadi pribadi yang gemar dan suka melakukan perilaku atau berbuat yang baik.

Seorang guru yang bijaksana harus memulai pendidikan dengan memberi hadiah dan segala macam jenisnya sebelum memberi sanksi. Reward itu tidak harus berupa materi, apresiasi yang baik juga merupakan hadiah. Reward diberikan dengan syarat : a) hanya diberikan pada anak yang telah mendapatkan prestasi yang baik, b) jangan menjanjikan ganjaran/hadiah lebih dulu sebelum anak berprestasi. c) diberikan dengan hati-hati jangan sampai anak menganggapnya sebagai upah, d) jangan sampai menimbulkan kecemburuan bagi anak yang lain, namun sebaiknya harus menimbulkan semangat dan motivasi bagi anak didik yang lain. Secara kongkret ganjaran atau reward dalam pendidikan tidak hanya berupa materi, apresiasi yang baik juga merupakan reward yang bernilai tinggi.

Selanjutnya, reward hendaknya diberikan dengan tujuan: a. membangkitkan dan merangsang belajar anak, lebih-lebih bagi anak yang malas dan lemah. b. mendorong anak agar selalu melakukan perbuatan yang lebih baik lagi. c. Menambah kegiatannya atau kegairahannya dalam belajar. ${ }^{32}$ Seorang guru ketika ada di dalam kelas, menjadi percontohan bagi anak didiknya. Dengan demikian, guru harus memberikan percontohan yang baik kepada anak didiknya.

\footnotetext{
${ }^{31}$ Hakim, 88.

32 Rusdiana Hamid, "Reward Dan Punishment Dalam Perspektif Pendidikan Islam" 4 (2006): 69.
} 


\section{Metode Penelitian}

Penelitian ini adalah penelitian kualitatif dengan rancangan studi kasus tunggal (single case study) yang arah penelitiannya terpusat pada satu kasus atau satu fenomena saja. Dalam studi kasus tunggal umumnya tujuan atau fokus penelitian langsung mengarah pada konteks atau inti dari permasalahan.

Sumber data primer diperoleh dari kata-kata dan tindakan informan. Dalam menentukan informan maka peneliti menggunakan pengambilan sampel secara purposive, internal, dan time sampling. Berdasarkan pada teknik purposive, peneliti menetapkan informan kunci yaitu dewan guru yang mengetahui tentang implementasi pendidikan agama Islam nirkekerasan di SD Muhammadiyah 1 Sidoarjo. Sumber data sekunder dari penelitian ini adalah peristiwa dan dokumen. Peristiwa digunakan untuk mengetahui bagaimana proses atau program pembelajaran yang dilakukan sebagai tindak lanjut dari perencanaan strategis yang dilakukan. Dokumen merupakan bahan tertulis atau benda yang berhubungan dengan fokus penelitian.

Analisis data adalah sebuah proses yang dilakukan melalui pencatatan, penyusunan, pengolahan dan penafsiran serta menghubungkan makna data yang ada dalam kaitannya dengan masalah penelitian. ${ }^{33}$ Data yang telah diperoleh melalui wawancara, observasi dan dokumentasi maka peneliti melakukan analisis melalui pemaknaan atau proses interpretasi terhadap data-data yang telah diperoleh. Analisis yang dimaksud merupakan upaya mencari dan menata secara sistematis catatan hasil observasi, wawancara dan dokumentasi untuk meningkatkan pemahaman peneliti tentang persoalan yang diteliti dan menyajikan sebagai temuan lapangan.

\footnotetext{
33 Nana Sudjana and Awal Kusumah, Proposal Penelitian Di Perguruan Tinggi (Bandung: Sinar Baru Algesindo, 2000), 89.
} 


\section{PAI Nirkekerasan Mengajarkan Anti Bullying}

Tindak kekerasan di sekolah atau sering kita kenal dengan bullying, dapat terjadi di manapun dan kapanpun, sekalipun itu di lingkungan sekolah. Untuk itu, pencegahan sudah selayaknya dilakukan setiap saat. Upaya tersebut bias dilakukan dengan mengambil kandungan dari al-Qur'an yang menjadi landasan utama dalam kehidupan seorang muslim untuk mendapatkan kehidupan yang baik di dunia maupun di akhirat kelak.

Berdasarkan temuan peneliti, pencegahan tindakan bullying tersebut dilakukan melalui guru stay. Pencegahan tindakan bullying menjadi prioritas demi terciptanya kenyamanan di lingkungan sekolah. Hal ini sesuai pendapat Abd. Rahman Assegaf yang menyatakan bahwa, damai dengan sesama berarti hidup rukun dengan sesama manusia, tidak berbuat jahat, bahkan berbuat baik kepada sesama manusia tanpa memandang perbedaan agama, warna kulit, ras, seks, suku, bangsa, bahasa, keturunan, kekayaan, pangkat atau kedudukan, dan lain sebagainya. ${ }^{34}$

Nilai-nilai yang ada dalam nirkekerasan "anti bullying" adalah saling menghormati, saling memahami, dan toleransi. Nilai-nilai tersebut urgen dimiliki peserta didik guna meminimalisir tindakan kekerasan baik secara fiskik maupun non fisik. Sehingga peserta didik dapat merasan aman, nyaman dan menyenangkan.

Namun upaya pencegahan tindak kekerasan masih belum maksimal. Hasil penelitian menunjukkan bahwa masih terjadi tindakan tidak menghormati pendapat teman sejawat “menertawakan jika ada yang tanya kepada guru”. Fenomena itu mengindikasikan bahwa peserta didik masih belum seutuhnya menghargai pendapat orang lain.

34 Assegaf, Pendidikan Tanpa Kekerasan: Tipologi Kondisi, Kasus Dan Konsep, 147. 
Selanjutnya, pembelajaran al-Qur'an yang diprioritaskan adalah mengambil isi kandungan untuk mengajarkan peserta didik bertindak dan bersikap. Hal ini sesuai pendapat Haryanto bahwa pandangan hidup yang mendasari seluruh kegiatan pendidikan dalam Islam haruslah sejalan dengan pandangan hidup Muslim, yaitu al-Qur'an yang merupakan nilai-nilai luhur yang bersifat universal dan Sunnah sebagai penjabaran alQur'an. Dalam hal ini, Ahmad D. Marimba dalam Haryanto mengatakan bahwa yang menjadi landasan atau dasar pendidikan diibaratkan sebagai sebuah bangunan sehingga isi alQur'an dan hadis menjadi fondasinya. Sebab keduanya menjadi sumber kekuatan dan keteguhan tetap berdirinya pendidikan. ${ }^{35}$

Adapun menurut Zakiah Darajat dalam Haryanto mengatakan bahwa Al-Qur'an merupakan sumber pendidikan yang terlengkap, baik itu pendidikan kemasyarakatan (sosial), moral (akhlak), spiritual (kerohanian), material (kejasmanian), dan alam semesta. Ia merupakan pedoman normatif-teoretis bagi pelaksanaan pendidikan Islam yang memerlukan penafsiran lebih lanjut bagi operasional pendidikan Islam. ${ }^{36}$

\section{PAI Nirkekerasan Menekankan Persaudaraan}

Konsep persudaraan atau dikenal dengan prinsip persamaan dalam pendidikan Islam menjadi hal yang sangat perlu dan penting untuk dijadikan landasan dalam menciptakan pendidikan Islam yang baik.

Berdasarkan hasil temuan penelitian, guru selalu memberikan contoh dalam pelaksanaan pembelajaran tentang bagaimana seharusnya seseorang bersikap baik antar siswa, dengan guru maupun orang tua. Hal itu sependapat dengan Haryanto bahwa prinsip persamaan berakar dari konsep dasar

\footnotetext{
${ }^{35}$ Haryanto Al-Fandi, Desain Pembelajaran Yang Demokratis Dan Humanis (Yogyakarta: Ar-Ruzz Media, 2011), 130.

${ }^{36}$ Al-Fandi, 132.
} 
tentang manusia yang mempunyai kesatuan asal yang tidak membedakan derajat, baik antara jenis kelamin, kedudukan sosial, bangsa, suku, ras, atau warna kulit. Oleh karena itu, budak sekalipun mendapatkan hak yang sama dalam pendidikan. Prinsip persamaan juga mengandung arti bahwa pendidikan Islam tidak mengenal perbedaan dan tidak membeda-bedakan latar belakang seseorang jika dia mau menuntut ilmu. ${ }^{37}$

Hasil penelitian menyatakan bahwa di sekolah ini kita tekankan dan terus tanamkan sikap persaudaraan antar teman atau sesama keluarga sekolah walaupun kelasnya berbeda. Kerukunan hidup antar teman akan memberikan lingkungan yang baik bagi semua, tidak hanya siswa tapi guru dan wali murid. Hal ini terkait dengan penyelarasan misi antar sekolah dengan orang tua.

Selain itu, persaudaraan juga dapat gunakan sebagai alat pemersatu bagi siswa, orang tua dan sekolah. Hal ini sesuai dengan Muhaimin yang berpendapat bahwa, pendidikan agama Islam adalah usaha sadar untuk menyiapkan peserta didik dalam meyakini, memahami, menghayati dan mengamalkan agama Islam melalui kegiatan bimbingan, pengajaran, dan/atau latihan dengan memperhatikan tuntutan untuk menghormati agama lain dalam kerukunan antar umat beragama dalam masyarakat untuk mewujudkan persatuan nasional. ${ }^{38}$

\section{PAI Nirkekerasan Membangun Sikap Toleransi}

Pendidikan akidah dengan mengajarkan shalat kepada anak, tentunya sebagai pendidikan dasar tentang kewajiban bagi orang Islam. Dalam pembelajaran di sini, tentunya memiliki manfaat yang besar kepada anak dan bernilai jangka panjang

\footnotetext{
${ }^{37}$ Al-Fandi, 141.

38 Muhaimin, Paradigma Pendidikan Islam; Upaya Mengefektifkan Pendidikan Agama Islam Di Sekolah (Bandung: Remaja Rosdakarya, 2012), 85.
} 
bagi dirinya untuk menjadi pribadi yang saleh dan salehah sebagaimana diharapkan oleh setiap orangtua kepada anaknya.

Menurut Rusli Karim dalam Haryanto mengatakan bahwa prinsip tauhid merupakan prinsip paling utama dalam pendidikan Islam. Dalam konsep pendidikan Islam, tauhid dikonstruksikan sebagai paradigma kebebasan manusia baik secara lahiriah maupun rohaniah, kecuali hanya kepada Allah SWT. Hal ini mengisyaratkan sebuah ajaran bahwasanya praktek pendidikan Islam tidak mengenal diskriminasi terhadap siapapun. $^{39}$

\section{Penutup}

Konsep pendidikan agama Islam (PAI) nirkekerasan di antaranya; pertama, pendidikan agama Islam nirkekerasan mengajarkan anti bullying. Kemudian, landasan atau dasar pendidikan diibaratkan sebagai sebuah bangunan sehingga kandungan al-Qur'an dan hadis menjadi fondasi berjalannya PAI nirkekerasan anti bullying. Kedua, pendidikan agama Islam nirkekerasan menekankan sifat saling menyayangi sesama (persaudaraan). Prinsip persamaan juga mengandung arti bahwa pendidikan Islam tidak mengenal perbedaan dan tidak membeda-bedakan latar belakang seseorang. Ketiga, pendidikan agama Islam nirkekerasan membangun sikap toleransi. Toleransi yang dibangun harus secara utuh melekat kepada peserta didik baik secara naluri maupun sikap sosial. Sikap toleransi tersebut dibagun melalui prinsip tauhid.

Strategi pembelajaran pendidikan agama Islam nirkekerasan sebagai berikut; pertama, melalui kurikulum yang mencakup: a) Tujuan pendidikan Islam haruslah berorientasi pada hakikat pendidikan yang meliputi tujuan dan tugas hidup manusia, memperhatikan sifat-sifat dasar (nature) manusia, tuntutan masyarakat, dimensi-dimensi kehidupan ideal Islam. b)

${ }^{39}$ Al-Fandi, Desain Pembelajaran Yang Demokratis Dan Humanis, 139. 
Bahan pelajaran. Mata pelajaran al Islam di SD Muhammadiyah 1 terfokus pada aspek: al-Quran dan al-hadits sebagai induk dan sumber ajaran Islam. Keimanan, merupakan aspek pembentukan aqidah yang kokoh dan benar. Ibadah, baik syariah maupun muamalah. Akhlak, hal-hal yang berkaitan dengan perilaku terpuji atau tercela. Sejarah Kebudayaan Islam, memberi bekal semangat juang dalam mengembangkan dan menegakkan agama Islam dengan contoh Rasulullah SAW. c) Kegiatan belajar mengajar proses interaksi antara seorang guru dengan siswa. d) Evaluasi dan penilaian dilakukan secara konsisten, sistematis, dan terprogram dengan menggunakan tes dan nontes. Kedua, melalui kegiatan pembiasaan. Kegiatan pembiasaan dilakukan dengan berbagai metode. Metode yang digunakan dalam pembelajaran untuk meminimalisir nirkekerasan yang terjadi di sekolah di antaranya: Metode amaliyah atau praktek, metode Amar ma'ruf nahi munkar, metode nasihat, metode Kisah, metode uswatun hasanah. Ketiga, melalui pemanfaatan media dan sumber belajar adalah alat bantu yang berguna dalam kegiatan belajar mengajar. Sumber pelajaran. Terkait dengan sumber pelajaran yang menjadi rujukan guru dalam mengajar, khususnya pendidikan agama Islam tentunya buku khusus pendidikan agama Islam.

\section{Daftar Rujukan}

Abu-Nimer, Mohammed. Nirkekerasan dan Bina Damai dalam Islam: Teori dan Praktik. Pustaka Alvabet, 2010.

Al-Fandi, Haryanto. Desain Pembelajaran Yang Demokratis Dan Humanis. Yogyakarta: Ar-Ruzz Media, 2011.

Amin, A. Rifki. Pengembangan Pendidikan Agama Islam Reinterpretasi Berbasis Interdisipliner. Yogyakarta: LKiS, 2015.

Arifin, Syamsul. Klaim Kemutlakan, Konflik Sosial, Dan Reorientasi Keberagaman, Dalam Agama Kekerasan: 
Membongkar Ekslusivisme, Ed. Armada Riyanto. Malang: Dioma, 2000.

Assegaf, Abd. Rahman. Pendidikan Tanpa Kekerasan: Tipologi Kondisi, Kasus Dan Konsep. Yogyakarta: Tiara Wacana, 2004.

Berger, Peter L. Tafsir Sosial Atas Kenyataan. Jakarta: LP3ES, 1990.

Candra, dkk, Novi Poespita. Sekolah Nir Kekerasan. Yogyakarta: Ifada Press, 2016.

Cowie, Helen, and Dawn Jennifer. Penangannan Kekerasan Di Sekolah "Pendekatan Lingkup Sekolah Untuk Mencapai Praktik Terbaik. Jakarta: Indeks, 2009.

"Deretan Kasus Kenakalan Bocah SMK Yang Aniaya Gurunya | Merdeka.Com." Accessed January 12, 2017. https://www.merdeka.com/peristiwa/deretan-kasuskenalan-bocah-smk-yang-aniaya-gurunya/kesal-dimintasabar-siswa-smk-di-solo-menganiaya-guru.html.

developer, mediaindonesia com. "Pendidikan dan Subkultur Nirkekerasan," May 2, 2017. http://mediaindonesia.com/read/detail/102904pendidikan-dan-subkultur-nirkekerasan.

"Dianiaya Teman, Siswa MI Di Sleman Kencing Darah Dan Nyaris Impoten | Merdeka.Com.” Accessed January 12, 2017. https://www.merdeka.com/peristiwa/dianiayateman-siswa-mi-di-sleman-kencing-darah-dan-nyarisimpoten.html.

Hakim, Muhammad Andi. "Meruntuhkan Budaya Kuasa Dan Kekerasan Pada Anak: Belajar Dari Ki Hadjar Dewantara." BUANA GENDER : Jurnal Studi Gender Dan Anak 1, no. 1 (June 28, 2016): 79-90. https://doi.org/10.22515/bg.v1i1.64.

Hamid, Rusdiana. "REWARD DAN PUNISHMENT DALAM PERSPEKTIF PENDIDIKAN ISLAM” 4 (2006): 13. 
Institute, The Wahid. Lampu Merah Kebebasan Beragama", Laporan Kebebasan Beragama Dan Toleransi Di Indonesia. Jakarta: The Wahid Institute, 2011.

Ma'arif, Syafi'i. Islam Dalam Bingkai KeIndonesiaan Dan Kemanusiaan. Jakarta: Mizan, 2009.

Melvin. Active Learning. Bandung: Nusamedia, 2011.

Muhaimin. Paradigma Pendidikan Islam; Upaya Mengefektifkan Pendidikan Agama Islam Di Sekolah. Bandung: Remaja Rosdakarya, 2012.

Purnomo, Agus. Ideologi Kekerasan: Argumentasi TeologisSosial Radikalisme Islam. Yogyakarta: Pustaka Pelajar, 2009.

Sudjana, Nana, and Awal Kusumah. Proposal Penelitian Di Perguruan Tinggi. Bandung: Sinar Baru Algesindo, 2000.

Tadjoeddin, Mohammad Zulfan, and United Nations Support Facility for Indonesian Recovery (UNSFIR) (Indonesia). Anatomi kekerasan sosial dalam konteks transisi: kasus Indonesia 1990-2001. Jakarta: UNSFIR, 2002.

"Taruna STIP Tewas Di Asrama, Diduga Dianiaya Seniornya Kompas.Com." Accessed January 12, 2017. https://megapolitan.kompas.com/read/2017/01/11/11200 271/taruna.stip.tewas.di.asrama.diduga.dianiaya.seniorny a.

Teori-teori kekerasan. Ghalia Indonesia, 2002.

Zainudin, Atiqa, and Dwi Purnanto. Radikalisme Keagamaan Dan Perubahan Sosial. Surakarta: MUP, 2002. 